Для цитирования: Сиденко Е.А., Михалев Д.Е., Какурина Г.В., Черемисина О.В., Байдик О.Д., Чойнзонов Е.Л., Кондакова И.В. Активность циркулирующих протеасом при опухолевых и предопухолевых заболеваниях органов головы и шеи. Сибирский онкологический журнал. 2021; 20(2): 46-52. - doi: 10.21294/1814-4861-2021-20-2-46-52

For citation: Sidenko E.A., Mikhalev D.E., Kakurina G.V., Cheremisina O.V., Baidik O.D., Choinzonov E.L., Kondakova I.V. The activity of circulating proteasomes in tumor and precancerous diseases of the head and neck organs. Siberian Journal of Oncology. 2021; 20(2): 46-52. - doi: 10.21294/1814-4861-2021-20-2-46-52

\title{
THE ACTIVITY OF CIRCULATING PROTEASOMES IN TUMOR AND PRECANCEROUS DISEASES OF THE HEAD AND NECK ORGANS
}

\section{E.A. Sidenko1,2, D.E. Mikhalev², G.V. Kakurina1, O.V. Cheremisina1', O.D. Baidik², E.L. Choinzonov ${ }^{1,2}$, I.V. Kondakova ${ }^{1}$}

Cancer Research Institute. Tomsk National Research Medical Center, Russian Academy of Sciences, Tomsk, Russia ${ }^{1}$

5, Kooperativny Street, 634009, Tomsk, Russia. E-mail: sidenkoevgeniyaaleksandrovna@gmail.com¹ Siberian State Medical University, Tomsk, Russia²

2, Moskovsky Trakt, 634050, Tomsk, Russia²

\section{Abstract}

Introduction. Identification of persons with a high oncological risk to squamous cell carcinoma of the head and neck region is an urgent problem for the early diagnosis of this disease. The activity of circulating proteasomes can be a criterion for predicting the risk of the larynx and oral cavity cancers in patients with precancerous diseases of the upper respiratory and gastrointestinal tracts. The aim of the study is to investigate the chymotrypsin-like and caspase-like activities of circulating serum proteasomes depending on the localization of precancerous and neoplastic diseases of the larynx and oral cavity. Material and Methods. The study population consisted of 35 patients with histologically verified HNSCC (T1-3N0-3M0), 15 patients with chronic hyperplastic laryngitis $(\mathrm{CHL})$ and oral leukoplakia, and 10 healthy volunteers who did not have chronic upper respiratory tract diseases in the acute stage. The median age of the patients was $53 \pm 5.3$ years. Results. An increase in the studied proteasome activities was found in the blood serum of patients with malignant tumors as compared with patients with chronic hyperplastic diseases associated with precancerous changes, as well as in the larynx and oral cavity cancers groups as compared with healthy donors. At the same time, depending on the localization of the pathological process, it was shown that only the chymotrypsin-like activity of the circulating pool of proteasomes significantly differs both in the groups of oral cancer leukoplakia, and in the groups of laryngeal cancer chronic hyperplastic laryngitis with dysplastic epithelial lesions. In addition, differences were found between chymotrypsin-like and caspase-like activities of circulating serum proteasomes in patients with chronic hyperplastic laryngitis with oral dysplasia and leukoplakia. Conclusion. The results obtained indicate that the determination of the CTP activity of the circulating pool of proteasomes can be used as a criterion for predicting the risk of the larynx and oral cavity cancers in patients with precancerous diseases of the larynx and oral cavity.

Key words: laryngeal cancer, oral cancer, dysplasia, chymotrypsin-like activity of proteasomes, caspase-like activity of proteasomes. 


\title{
АКТИВНОСТЬ ЦИРКУЛИРУЮЩИХ ПРОТЕАСОМ ПРИ ОПУХОЛЕВЫХ И ПРЕДОПУХОЛЕВЫХ ЗАБОЛЕВАНИЯХ ОРГАНОВ ГОЛОВЫ И ШЕИ
}

\author{
Е.А. Сиденко ${ }^{1,2}$, Д.Е. Михалев², Г.В. Какурина', О.В. Черемисина', \\ О.Д. Байдик', Е.Л. Чойнзонов ${ }^{1,2}$, И.В. Кондакова ${ }^{1}$
}

\begin{abstract}
Научно-исследовательский институт онкологии, Томский национальный исследовательский медицинский центр Российской академии наук, г. Томск, Россия ${ }^{1}$

Россия, 634009, г. Томск, пер. Кооперативный, 5.

E-mail: sidenkoevgeniyaaleksandrovna@gmail.com ${ }^{1}$

ФГБОУ ВО «Сибирский государственный медицинский университет» Минздрава России,

г. Томск, Россия ${ }^{2}$

Россия, 634050, г. Томск, Московский тракт, $2^{2}$
\end{abstract}

\section{Аннотация}

\begin{abstract}
Актуальность. Выявление лиц с высоким онкологическим риском развития плоскоклеточного рака области головы и шеи (ПРГШ) является актуальной проблемой для ранней диагностики этого заболевания. Критерием для прогноза риска возникновения ПРГШ у больных с предопухолевыми заболеваниями верхних отделов респираторного и желудочно-кишечного трактов может быть активность циркулирующих протеасом. Цель исследования - изучить химотрипсинподобную и каспазаподобную активности циркулирующих протеасом сыворотки крови в зависимости от локализации предопухолевых и опухолевых заболеваний гортани и ротовой полости. Материал и методы. В исследование вошли 35 пациентов с ПРГШ (Т1-3N0-3М0) с гистологически верифицированным диагнозом, 15 человек с хроническим гиперпластическим ларингитом (ХГЛ с DIIII), лейкоплакиями полости рта и 10 здоровых волонтеров, не имеющих хронических заболеваний верхних дыхательных путей в стадии обострения. Средний возраст больных составил $53 \pm$ 5,3 года. Результаты. Обнаружено повышение изучаемых активностей протеасом в сыворотке крови больных со злокачественной опухолью по сравнению с больными хроническими гиперпластическими заболеваниями, ассоциированными с предопухолевыми изменениями, а также в группах ПРГШ по сравнению со здоровыми донорами. В то же время в зависимости от локализации патологического процесса показано, что только химотрипсинподобная (ХТП) активность циркулирующего пула протеасом значимо различается как в группах рак ротовой полости - лейкоплакии, так и в группах рак гортани - хронический гиперпластический ларингит (ХГЛ) с диспластическими изменениями эпителия. Кроме того, были обнаружены различия между ХТП и каспазаподобной активностями циркулирующих протеасом сыворотки крови больных хроническим гиперпластическим ларингитом с дисплазиями и лейкоплакиями ротовой полости, а также у групп больных злокачественными опухолями этих локализаций. Выводы. Полученные результаты свидетельствуют о том, что определение ХТП активности циркулирующего пула протеасом может быть использовано в качестве критерия для прогноза риска возникновения ПРГШ у больных предопухолевыми заболеваниями гортани и ротовой полости.
\end{abstract}

Ключевые слова: рак гортани, рак ротовой полости, дисплазия, химотрипсинподобная активность протеасом, каспазаподобная активность протеасом.

\section{Introduction}

Although most of the head and neck organs can be visually and instrumentally inspected, squamous cell carcinoma of the upper respiratory and digestive systems is characterized by an asymptomatic course, late admission of patients to cancer centers, early onset of metastases and high mortality rate within the first year after diagnosis $[1,2]$. In most cases, the development of HNSCC follows an ordered series of steps beginning with epithelial cell hyperplasia followed by dysplasia. Grade II-III laryngeal dysplasia and oral leukoplakia is associated with high risk of progression to carcinoma $[3,4]$. Thus, it is important to develop predictive markers that may identify lesions at high risk of progression to malignancy.
Tumor transformation occurs with the participation of many processes, one of which is proteolysis. Intracellular proteolysis occurs mainly in proteasomes, multisubunit complexes. Proteasomes are the main non-lysosomal proteases in eukaryotic cells, which are responsible for the degradation of all short-lived proteins and 70-90\% of all long-lived proteins [5]. Proteasomes are known to be involved in the cleavage of growth factors, their receptors, components of signaling pathways, and transcription factors $[6,7]$. The proteasome is made of two subcomplexes: the $20 \mathrm{~S}$ proteasome and the proteasome activator. All proteasomes have three types of active sites: caspaselike, trypsin-like, and chymotrypsin-like. To date, the existence of extracellular forms of proteasomes 
circulating in various biological fluids of the body has been proven $[8,9]$. They can be found and transported both as part of microvesicles, in particular, exosomes, and in free form, circulating in the bloodstream [9, 10]. Proteolytic activity is possessed by proteasomes in a free, non-vesicular form. Circulating proteasomes in human plasma are present in the form of a $20 \mathrm{~S}$ pool, and their levels increase significantly in various pathological conditions, including cancer, autoimmune diseases, trauma, and sepsis [11].

Proteasomes are involved in the pathogenesis of many cancers including breast, endometrial, and thyroid cancers $[12,13]$. We previously showed that the the ChTL and CL levels were higher in patients with HNSCC than in patients with chronic laryngeal hyperplasia associated with epithelial dysplasia. The levels of ChTL and CL proteasomal activity did not depend on the tumor stage but depended on the tumor grade [14]. The purpose of the study was to assess the ChTL and CL activities of circulating proteasomes in patients with premalignant and malignant oral and laryngeal lesions.

\section{Material and Methods}

The study population consisted of 35 patients with histologically verified HNSCC (T1-3N0-3M0), who had not received previous special treatment, 15 patients with chronic hyperplastic laryngitis (CHL) and oral leukoplakia, and 10 healthy volunteers who did not have chronic upper respiratory tract diseases in the acute stage. The median age of the patients was $53 \pm 5.3$ years. The study included patients with $\mathrm{HN}$ SCC, who were treated at the Head and Neck Cancer Department of Cancer Research Institute, patients with CHL, who were examined at the Endoscopy Department of Cancer Research Institute and patients with oral leukoplakia, who were observed at the Dentistry Department of Siberian State Medical University (Tomsk, Russia). The study was conducted under conditions of voluntary participation and confidentiality in accordance with the World Medical Association's Declaration of Helsinki «Ethical Principles for Medical Research involving Human Subjects», as revised in 2000. This study was approved by the Ethics Committee of the Cancer Research Institute. Prior to the study, serum samples were frozen and stored at $-80{ }^{\circ} \mathrm{C}$.

To assess the chymotrypsin-like (ChTL) and caspase-like (CL) activities of circulating proteasomes, blood serum was pre-activated with $10 \%$ SDS according to the technique [15]. The ChTL activity of circulating proteasomes was determined by the hydrolysis of the fluorogenic oligopeptide Suc-LLVYAMC (Sigma); the CL activity was determined by the hydrolysis of the fluorogenic oligopeptide Z-LLEAMC (Sigma). The reaction was carried out for 20 minutes at $37^{\circ} \mathrm{C}$. The resulting product was recorded on a Cytation1 multi-mode microplate reader-imager (BioTek, United States) at Exi $=360 \mathrm{~nm}, \mathrm{Emi}=460 \mathrm{~nm}$.
The specific activity of proteasomes was expressed in units of activity per $1 \mathrm{ml}$ of serum.

Statistical analysis was carried out using the Statistica 10.0 software package. The results shown in the table are presented as median (Me) with an interquartile range (Q1Q3). Using the Kruskal-Wallis test, statistically significant differences were found between the study groups. For further pairwise comparison, the nonparametric Mann-Whitney test was used taking into account the correction for multiple comparisons (Bonferroni correction). Differences were considered significant at $\mathrm{p}<0.05$.

\section{Results and Discussion}

Table 1 shows the ChTL and CL activities of circulating proteasomes in blood serum of patients with HNSCC, patients with chronic premalignant lesions, and healthy donors. Significant differences in serum proteasome ChTL and CL activities between patients with HNSCC and patients with chronic oral and laryngeal lesions associated with dysplastic changes as well as between patients with HNSCC and healthy donors were found. As the disease severity increased, the serum proteasome ChTL and CL activities also increased. The data obtained confirm our previous findings that the proteasome ChTL activity was higher in patients with HNSCC compared to patients with CHL with grade II-III dysplasia [14]. In addition, a significant increase in the CL level was also observed in the same groups of patients. Thus, the development of oral and laryngeal cancers was associated with significant changes in the proteasome ChTL and CL activities.

We also compared serum proteasome ChTL and $\mathrm{CL}$ activities in patients with premalignant laryngeal and oral lesions (table 2).

The levels of ChTL and CL proteasomal activities were significantly higher in patients with CHL (grade IIII dysplasia) than in patients with oral leukoplakia. Among HNSCC patients, the levels of ChTL and CL proteasomal activities were higher in laryngeal cancer patients than in oral cancer patients (table 3). Moreover, the comparison of malignant and premalignant lesions revealed a significant difference in the ChTL proteasomal activity between patients with oral cancer and patients with oral leukoplakia as well as between patients with laryngeal cancer and patients with $\mathrm{CHL}$ with epithelial dysplasia.

A significant difference in the ChTL activity of circulating proteasomes between premalignant and malignant lesions shows that proteasomes are likely to be involved in malignant transformation of precancerous lesions into cancer.

The role of circulating proteasomes in the development of cancer is not clear. Increased levels of their activity were shown to correlate with the progression of solid tumors, including laryngeal cancer $[14,16]$. Proteasomes are believed can enter the systemic circulation during secretion from cells by the mecha- 
Химотрипсинподобная (ХTП) и каспазаподобная (КП) активности циркулирующих протеасом сыворотки крови больных ПРГШ и хроническими заболеваниями с предопухолевыми изменениями The chymotrypsin-like (ChTL) and caspase-like (CL) activities of circulating proteasomes in blood serum of patients with HNSCC, patients with chronic premalignant lesions, and healthy donors

\begin{tabular}{|c|c|c|}
\hline Исследуемые группы/Study groups & $\begin{array}{c}\text { ХТП/ChTL } \\
(\text { ЕД/мл/U/ml) }\end{array}$ & $\begin{array}{c}\text { КП/CL } \\
\text { (ЕД/мл/U/ml) }\end{array}$ \\
\hline $\begin{array}{c}\text { Здоровые доноры }(\mathrm{n}=10) / \\
\text { Healthy donors }(\mathrm{n}=10)\end{array}$ & $\begin{array}{c}81.2 \\
(65.0-101.6)\end{array}$ & $\begin{array}{c}106.2 \\
(86.6-139.5)\end{array}$ \\
\hline $\begin{array}{c}\text { ХГЛ с DI-III, лейкоплакии }(\mathrm{n}=15) / \\
\text { CHL with grade I-III dysplasia, leukoplakia (n=15) }\end{array}$ & $\begin{array}{c}95.3 \\
(69.2-117.0)\end{array}$ & $\begin{array}{c}160.0 \\
(153.7-200.0) \\
p=0.030\end{array}$ \\
\hline ПРГШ $(\mathrm{n}=35) / \mathrm{HNSCC}(\mathrm{n}=35)$ & $\begin{array}{c}150.0 \\
(117.0-200.0) \\
\mathrm{p}=0.001 ; \mathrm{p} 1<0.001\end{array}$ & $\begin{array}{c}253.3 \\
(156.6-310.0) \\
\mathrm{p}=0.001 ; \mathrm{p} 1=0.020\end{array}$ \\
\hline
\end{tabular}

Примечание: $\mathrm{p}$ - значимость различий между здоровыми донорами и группой больных с ПРГШ; р1 - значимость различий между группами больных с ХГЛ с DI-III, лейкоплакии и с ПРГШ.

Notes: $\mathrm{p}$ - significant difference in ChTL and CL activities between healthy donors and patients with HNSCC; p1 - significant difference in ChTL and CL activities between patients with chronic premalignant lesions (CHL with dysplasia and leukoplakia) and patients with HNSCC.

Таблица 2/Table 2

Химотрипсинподобная (ХТП) и каспазаподобная (КП) активности циркулирующих протеасом сыворотки крови больных хроническим гиперпластическим ларингитом с дисплазией (ХГЛ) и лейкоплакиями ротовой полости

Serum proteasome ChTL and CL activities in patients with chronic hyperplastic laryngitis (CHL) with dysplasia and in patients with oral leukoplakia

\begin{tabular}{|c|c|c|}
\hline Исследуемые группы/Study groups & $\begin{array}{c}\text { ХТП/ChTL } \\
(\text { ЕД/мл/U/ml) }\end{array}$ & $\begin{array}{c}\text { КП/CL } \\
\text { (ЕД/мЛ/U/ml) }\end{array}$ \\
\hline ХГЛ (DI-III) (n=9)/CHL (grade I-III dysplasia) (n=9) & $\begin{array}{c}103.3 \\
(95.3-127,4)\end{array}$ & $\begin{array}{c}200.0 \\
(183.0-267.0)\end{array}$ \\
\hline Лейкоплакии ротовой полости (n=6)/Oral leukoplakia (n=6) & $\begin{array}{c}57.2 \\
(41.2-74.7) \\
p=0.030\end{array}$ & $\begin{array}{c}128.4 \\
(90.8-159.3) \\
p=0.003\end{array}$ \\
\hline
\end{tabular}

Примечание: $\mathrm{p}$ - значимость различий между группами больных с ХГЛ (DI-III) и с лейкоплакиями ротовой полости.

Notes: p - significant difference in ChTL and CL activities between patients with CHL (grade I-III dysplasia) and patients with oral lekoplakia.

Таблица 3/Table 3

Химотрипсинподобная (ХTП) и каспазаподобная (КП) активности циркулирующих протеасом сыворотки крови больных с предопухолевыми и опухолевыми заболеваниями органов головы и шеи The ChTL and CL activities of circulating proteasomes in blood serum of patients with premalignant and malignant head and neck lesions

\begin{tabular}{|c|c|c|}
\hline Исследуемые группы/Study groups & $\begin{array}{c}\text { ХТП/ChTL } \\
\text { (ЕД/мл/U/ml) }\end{array}$ & $\begin{array}{c}\text { КП/CL } \\
\text { (ЕД/мЛ/U/ml) }\end{array}$ \\
\hline Лейкоплакии (n=6)/Leukoplakia (n=6) & $\begin{array}{c}57.2 \\
(41.2-74.7)\end{array}$ & $\begin{array}{c}128.4 \\
(90.8-159.3)\end{array}$ \\
\hline Рак ротовой полости $(\mathrm{n}=10) /$ Oral cancer $(\mathrm{n}=10)$ & $\begin{array}{c}116.8 \\
(90.0-150.0) \\
p=0.009\end{array}$ & $\begin{array}{c}146.0 \\
(103.0-183.3)\end{array}$ \\
\hline ХГЛ (DI-III) (n=9)/CHL (grade I-III dysplasia) $(n=9)$ & $\begin{array}{c}103.3 \\
(95.3-127.4)\end{array}$ & $\begin{array}{c}200.0 \\
(183.0-267.0)\end{array}$ \\
\hline Рак гортани $(\mathrm{n}=25) /$ Laryngeal cancer $(\mathrm{n}=25)$ & $\begin{array}{c}160.0 \\
(140.0-217.0) \\
\mathrm{p} 1=0.010 ; \mathrm{p} 2=0.050\end{array}$ & $\begin{array}{c}281.6 \\
(233.0-338.3) \\
\text { p2 }=0.040\end{array}$ \\
\hline
\end{tabular}

Примечание: $\mathrm{p}$ - значимость различий между группами больных раком ротовой полости и больными с лейкоплакиями; $\mathrm{p}^{1}-$ значимость различий между группами больных раком гортани и больными с ХГЛ (DI-III)»; p $^{2}$ - значимость различий между группами больных с ХГЛ (DI-III) и больными с лейкоплакиями.

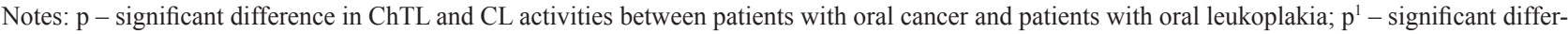
ence in ChTL and CL activities between patients with laryngeal cancer and patients with CHL with grade I-III dysplasia; $\mathrm{p}^{2}-$ significant difference in ChTL and CL activities between patients with CHL with grade I-III dysplasia and patients with oral leukoplakia. 
nism, which has not been established yet [17] or from destroyed microvesicles [13]. Determination of the function and substrates of circulating proteasomes showed that they can degrade albumin [18] and osteopontin [19]. It was found that the processing of osteopontin in the circulating proteasomes produced biologically active peptides with chemotactic activity [19]. It has not yet been determined whether there are other substrates for circulating proteasomes in the systemic circulation and what their significance is in pathological conditions.

The study of proteasomes in various malignant tumors is relevant not only from the point of view of the development of new therapeutic agents, the targets of which are active centers or subunits of proteasomes [20], but also for the search for new predictive cancer markers. The data obtained can serve as a basis for the development of a new method for assessing the

\section{ЛИТЕРАТУPA/REFERENCES}

1. Кожанов А.Л. Современные аспекты диагностики и лечения рака гортани. Голова и шея. 2016; 4: 29-35. [Kozhanov A.L. Current aspects of laryngeal cancer diagnostics and treatment. Head and Neck Journal. 2016; 4: 29-35. (in Russian)].

2. Zhu K., Lin R., Zhang Z., Chen H., Rao X. Impact of prior cancer history on the survival of patients with larynx cancer. BMC Cancer. 2020 Nov 23; 20(1): 1137. doi: 10.1186/s12885-020-07634-2.

3. Leemans C.R., Braakhuis B.J., Brakenhoff R.H. The molecular biology of head and neck cancer. Nat Rev Cancer. 2011; 11(1): 9-22. doi: $10.1038 /$ nrc2982.

4. de Boer D.V., Brink A., Buijze M., Stigter-van Walsum M., Hunter K.D., Ylstra B., Bloemena E., Leemans C.R., Brakenhoff R.H. Establishment and Genetic Landscape of Precancer Cell Model Systems from the Head and Neck Mucosal Lining. Mol Cancer Res. 2019 Jan; 17(1): 120-130. doi: 10.1158/1541-7786.MCR-18-0445.

5. Račková L., Csekes E. Proteasome Biology: Chemistry and Bioengineering Insights. Polymers (Basel). 2020; 12(12): 2909. doi: 10.3390/ polym 12122909.

6. Morozov A.V., Karpov V.L. Proteasomes and Several Aspects of Their Heterogeneity Relevant to Cancer. Front Oncol. 2019 Aug 13; 9: 761. doi: 10.3389/fonc.2019.00761.

7. Rousseau A., Bertolotti A. Regulation of proteasome assembly and activity in health and disease. Nat Rev Mol Cell Biol. 2018 Nov; 19(11): 697-712. doi: 10.1038/s41580-018-0040-Z

8. Bonella F. Sixt S.U., Thomassen J., Schmidt M., Cai M., Mori T. Guzman J., Costabel U. Extracellular 20S proteasome in BAL and serum of patients with alveolar proteinosis. Immunobiology. 2015 Mar; 220(3): 382-8. doi: 10.1016/j.imbio.2014.10.010.

9. Шамова Е.Е., Колегова Е.С., Кондакова И.В., Завьялов А.А. Внутриклеточный и циркулирующий пулы протеасом: значение при злокачественных новообразованиях различных локализаций. Сибирский онкологический журнал. 2015; (6): 76-82. [Shashova E.E., Kolegova E.S., Kondakova I.V., Zavyalov A.A. The intracellular and circulating pools of proteasomes: the value at cancer in different locations. Siberian Journal of Oncology. 2015; (6): 76-82. (in Russian.]

10. Bochmann I., Ebstein F., Lehmann A., Wohlschlaeger J., Sixt S.U., Kloetzel P.M., Dahlmann B. T lymphocytes export proteasomes by way of microparticles: a possible mechanism for generation of extracellular proteasomes. J Cell Mol Med. 2014; 18(1): 59-68. doi: 10.1111/jcmm.12160.

11. Kumar Deshmukh F., Yaffe D., Olshina M.A., Ben-Nissan G., Sharon M. The Contribution of the 20S Proteasome to Proteostasis. Biomolecules. 2019 May 16; 9(5): 190. doi: 10.3390/biom9050190.

12. Кондакова И.В., Спирина Л.В., Шашова Е.Е., Коваль В.Д., Коломиеч Л.А., Чернышова А.Л., Слонимская Е.М. Активность протеасом в опухолях женской репродуктивной системы. Биоорганическая химия. 2012; 38(1): 106-110. [Kondakova I.V., Spirina L.V., Shashova E.E., Koval V.D., Kolomiets L.A., Chernyshova A.L., Slonimskaya E.M. Proteasome activity in tumors of the female reproductive system. Russian Journal of Bioorganic Chemistry. 2012; 38(1): 89-92. (in Russian)]. doi: 10.1134/s106816201201013x. cancer risk in patients with precancerous oral and laryngeal diseases.

\section{Conclusion}

In this study, we analyzed for the first time the ChTL and CL activities of circulating proteasomes in the blood serum of patients with premalignant and malignant head and neck lesions. It was found that the levels of ChTL and CL proteasomal activities were significantly higher in patients with laryngeal and oral cancer than in patients with laryngeal dysplasia and oral laukoplakia. Moreover, significant differences in the ChTL and CL proteasomal activities between patients with CHL + dysplasia and patients with oral leukoplakia were observed. Thus, the results obtained indicate that the assessment of the ChTL and CL activities of circulating proteasomes can be used as a criterion for predicting the risk of developing HNSCC in patients with premalignant oral and laryngeal lesions.

13. Шамова Е.Е., Астахова Т.М., Плеханова А.С., Богомягкова Ю.В., Люпина Ю.В., Сумеди И.Р., Слонимская Е.М., Ерохов П.А., Абрамова Е.Б., Родоман Г.В., Кузнецов Н.А., Кондакова И.В., Шарова Н.П., Чойнзонов Е.Л. Изменение химотрипсинподобной активности протеасом в развитии карцином молочной и щитовидной желез человека. Бюллетень экспериментальной биологии и медицины. 2013; 156(8): 209-211. [Shashova E.E., Astakhova T.M., Plekhanova A.S., Bogomyagkova Y.V., Lyupina Y.V., Sumedi I.R., Slonimskaya E.M., Erokhov P.A., Abramova E.B., Rodoman G.V., Kuznetsov N.A., Kondakova I.V., Sharova N.P., Choinzonov E.L. Changes in proteasome chymotrypsinlike activity during the development of human mammary and thyroid carcinomas. Bulletin of Experimental Biology \& Medicine. 2013; 156(2): 242-244. (in Russian)]. doi: 10.1007/s10517-013-2321-z.

14. Какурина Г.В., Черемисина О.В., Чойнзонов Е.Л., Кондакова И.В. Циркулирующие протеасомы в патогенезе плоскоклеточного рака головы и шеи. Бюллетень экспериментальной биологии и медицины. 2017; 163 (1): 108-111. [Kakurina G.V., Cheremisina O.V., Choinzonov E.L., Kondakova I.V. Circulating proteasomes in the pathogenesis of head and neck squamous cell carcinoma. Bulletin of Experimental Biology \& Medicine. 2017; 163(1): 92-94. (in Russian)]. doi: 10.1007/s10517-017-3745-7

15. Ma W., Kantarjian H., Bekele B., Donahue A.C., Zhang X., Zhang Z.J., O'Brien S., Estey E., Estrov Z., Cortes J., Keating M., Giles F., Albitar $M$. Proteasome enzymatic activities in plasma as risk stratification of patients with acute myeloid leukemia and advanced-stage myelodysplastic syndrome. Clin Cancer Res. 2009 Jun 1; 15(11): 3820-6. doi: 10.1158/1078-0432.CCR-08-3034.

16. Heubner M., Wimberger P., Dahlmann B., Kasimir-Bauer S., Kimmig R., Peters J., Wohlschlaeger J., Sixt S.U. The prognostic impact of circulating proteasome concentrations in patients with epithelial ovarian cancer. Gynecol Oncol. 2011 Feb; 120(2): 233-8. doi: 10.1016/j. ygyno.2010.10.014.

17. Diakonov E.E., Selenina A.V., Tomilin A.N., Tsimokha A.S. Evidences against vesicle-dependent trafficking and involvement of extracellular proteasomes into cell-to-cell communications. Biochem Biophys Res Commun. 2019 Jan 8; 508(2): 368-373. doi: 10.1016/j. bbrc.2018.11.152

18. Sixt S.U., Beiderlinden M., Jennissen H.P., Peters J. Extracellular proteasome in the human alveolar space: a new housekeeping enzyme? Am J Physiol Lung Cell Mol Physiol. 2007; 292(5): L1280-8. doi: 10.1152/ ajplung.00140.2006.

19. Dianzani C., Bellavista E., Liepe J., Verderio C., Martucci M., Santoro A., Chiocchetti A., Gigliotti C.L, Boggio E., Ferrara B., Riganti L., Keller C., Janek K., Niewienda A., Fenoglio C., Sorosina M., Cantello R., Kloetzel P.M., Stumpf M.P., Paul F., Ruprecht K., Galimberti D., Martinelli Boneschi F., Comi C., Dianzani U., Mishto M. Extracellular proteasome-osteopontin circuit regulates cell migration with implications in multiple sclerosis. Sci Rep. 2017 Mar 9; 7: 43718. doi: 10.1038/srep43718.

20. Roeten M.S.F., Cloos J., Jansen G. Positioning of proteasome inhibitors in therapy of solid malignancies. Cancer Chemother Pharmacol. 2018 Feb; 81(2): 227-243. doi: 10.1007/s00280-017-3489-0.

Поступила/Received 28.01.2021

Принята в печать/Accepted 15.02.2021 


\section{СВЕДЕНИЯ ОБ АВТОРАХ}

Сиденко Евгения Александровна, аспирант лаборатории биохимии опухолей, Научно-исследовательский институт онкологии, Томский национальный исследовательский медицинский центр Российской академии наук (г. Томск, Россия). SPIN-код: 37360140. Author ID (Scopus): 57216126104. ORCID: 0000-0001-5838-9459. Researcher ID (WOS): AAG-1291-2021.

Михалев Дмитрий Евгеньевич, аспирант кафедры стоматологии, ФГБОУ ВО «Сибирский государственный медицинский университет» Минздрава России (г. Томск, Россия). SPIN-код: 3978-9130. ORCID: 0000-0002-5899-3872.

Какурина Гелена Валерьевна, кандидат медицинских наук, старший научный сотрудник, лаборатория биохимии опухолей, Научно-исследовательский институт онкологии, Томский национальный исследовательский медицинский центр Российской академии наук (г. Томск, Россия). SPIN-код: 1896-3144. Researcher ID (WOS): C-8668-2012. Author ID (Scopus): 23667534500. ORCID: 0000-0002-4506-9429.

Черемисина Ольга Владимировна, доктор медицинских наук, заведующая эндоскопическим отделением, Научноисследовательский институт онкологии, Томский национальный исследовательский медицинский центр Российской академии наук (г. Томск, Россия). SPIN-код: 9579-2691. Researcher ID (WOS): C-9259-2012. Author ID (Scopus): 6602197938. ORCID: 0000-0001-7234-4708.

Байдик Ольга Дмитриевна, доктор медицинских наук, заведующая кафедрой стоматологии, ФГБОУ ВО «Сибирский государственный медицинский университет» Минздрава России (г. Томск, Россия). SPIN-код: 4259-9842. Author ID (PИНЦ): 639612. Researcher ID (WOS): H-7849-2016. ORCID: 0000-0002-4748-4175.

Чойнзонов Евгений Лхамацыренович, доктор медицинских наук, профессор, академик РАН, заведующий отделением опухолей головы и шеи, директор, Научно-исследовательский институт онкологии, Томский национальный исследовательский медицинский центр Российской академии наук (г. Томск, Россия). SPIN-код: 2240-8730. Researcher ID (WOS): P-1470-2014. Author ID (Scopus): 6603352329. ORCID: 0000-0002-3651-0665.

Кондакова Ирина Викторовна, доктор медицинских наук, профессор, заведующая лабораторией биохимии опухолей, Научно-исследовательский институт онкологии, Томский национальный исследовательский медицинский центр Российской академии наук (г. Томск, Россия). SPIN-код: 9338-4149. Researcher ID (WOS): C-8658-2012. Author ID (Scopus): 6701872510. ORCID: 0000-0002-0947-8778.

\section{ВКЛАД АВТОРОВ}

Сиденко Евгения Александровна: исследование показателей в сыворотке крови флуориметрическим методом, статистическая обработка материала.

Михалев Дмитрий Евгеньевич: набор клинического материала.

Какурина Гелена Валерьевна: составление базы данных.

Черемисина Ольга Владимировна: набор клинического материала, критический пересмотр с внесением ценного интеллектуального содержания.

Байдик Ольга Дмитриевна: критический пересмотр с внесением ценного интеллектуального содержания.

Чойнзонов Евгений Лхамацыренович: разработка концепции научной работы.

Кондакова Ирина Викторовна: анализ научной работы, написание рукописи.

\section{Финансирование}

Работа выполнена в рамках Государственного задания на 2021 г. в НИИ онкологии Томского НИМЦ.

Конфликт интересов

Авторы заявляют об отсутствии конфликта интересов.

\section{ABOUT THE AUTHORS}

Evgenia A. Sidenko, Postgraduate, Laboratory of Tumor Biochemistry, Cancer Research Institute, Tomsk National Research Medical Center (Tomsk, Russia). Author ID (Scopus): 57216126104. ORCID: 0000-0001-5838-9459. Researcher ID (WOS): AAG-12912021.

Dmitry E. Mikhalev, Postgraduate, Dentistry Department, Siberian State Medical University (Tomsk, Russia). ORCID: 0000-00025899-3872.

Gelena V. Kakurina, PhD, Senior Researcher, Laboratory of Tumor Biochemistry, Cancer Research Institute, Tomsk National Research Medical Center (Tomsk, Russia). Researcher ID (WOS): C-8668-2012. Author ID (Scopus): 23667534500. ORCID: 0000-0002-45069429.

Olga V. Cheremisina, MD, DSc, Head of Endoscopy Department, Cancer Research Institute, Tomsk National Research Medical Center (Tomsk, Russia). Researcher ID (WOS): C-9259-2012. Author ID (Scopus): 6602197938. ORCID: 0000-0001-7234-4708.

Olga D. Baidik, MD, DSc, Head of Dentistry Department, Siberian State Medical University (Tomsk, Russia). Researcher ID (WOS): H-7849-2016. ORCID: 0000-0002-4748-4175.

Evgeny L. Choynzonov, MD, DSc, Professor, Member of the Russian Academy of Sciences, Director of Cancer Research Institute, Tomsk National Research Medical Center (Tomsk, Russia). Researcher ID (WOS): P-1470-2014. Author ID (Scopus): 6603352329. ORCID: 0000-0002-3651-0665. 
Irina V. Kondakova, DSc, Professor, Head of Laboratory of Tumor Biochemistry, Cancer Research Institute, Tomsk National Research Medical Center (Tomsk, Russia). Researcher ID (WOS): C-8658-2012. Author ID (Scopus): 6701872510. ORCID: 0000-0002-09478778 .

\section{AUTHOR CONTRIBUTION}

Evgenia A. Sidenko: data collection, data analysis and interpretation, statistical analysis, drafting of the manuscript.

Dmitry E. Mikhalev: data collection.

Gelena V. Kakurina: data analysis and interpretation.

Olga V. Cheremisina: data collection, critical revision of the manuscript for important intellectual content.

Olga D. Baidik: critical revision of the manuscript for important intellectual content.

Evgeny L. Choynzonov: study conception and design.

Irina V. Kondakova: study supervision, final approval of the manuscript.

\section{Funding}

The study was conducted within the framework of the State Assignment for 2021 at the Cancer Research Institute, Tomsk National Research Medical Center.

Conflict of interest

The authors declare that they have no conflict of interest. 